\title{
Rockin evoluutio venäläisessä elokuvassa
}

Ira Österberg

Katsoin viime viikonloppuna nelivuotiaan poikani kanssa elokuvaa, jossa pieni poika samoilee koiransa kanssa vuoristomaisemassa. Idyllisen vehreitä näkymiä säesti kaunis laulu lapsen rakkaudesta koiraansa. Yhtäkkiä poikani kääntyi puoleeni ja kysyi ihmeissään: "Äiti, mistä tuo musiikki oikein tulee?" Sillä hetkellä olin haljeta onnesta: tällä pienellä ja suoraviivaisella kysymyksellä poikani tarjosi paitsi erinomaisen aloituksen väitöslektiolleni myös täydellisen perustelun koko väitöskirjani kysymyksenasettelulle.

Tutkimukseni lähtökohtana on ajatus siitä, että elokuvissa on oikeastaan kahta erityyppistä musiikkia. Nämä kaksi musiikkityyppiä eivät ole itsestään selvä välttämättömyys, vaan niiden olemassaolo määrittyy ensisijaisesti elokuvallisten konventioiden kautta. Tällaiset konventiot eivät kuitenkaan koskaan ole kiveen hakattuja, vaan ne voivat muuttua ajan myötä. Muutos ei välttämättä ole kovin yksinkertainen prosessi, vaan saattaa vaatia useampia eri vaiheita konventioiden evoluutiossa. Ennen tämän muutosprossin mekaniikan hienovaraisempaa käsittelyä havainnollistan elokuvamusiikin kahta tyyppiä sangen äärimmäisillä, mutta helposti lähestyttävillä esimerkeillä.

Tuulen viemää -elokuvassa (Gone With The Wind, USA 1939) on kohtaus, jossa Scarlett O'Hara päätyy kuopimaan maasta kitkeriä juuria syötäväksi, mutta nousee sitten uhmakkaana ja vannoo kameralle, ettei tule koskaan enää näkemään nälkää. Scarlettin monologin aikana Max Steinerin klassisen romanttiseen idiomiin säveltämä instrumentaali orkesterimusiikki mukailee puheen tunnelmia hellästi ja hillitysti taustalla. Se on sävelletty varta vasten käytettäväksi musiikkina juuri tähän elokuvaan. Se on siis alkuperäismusiikkia, joka monen musiikkitieteilijän näkökulmasta on sitä oikeaa, varsinaista elokuvamusiikkia (esim. Brown 1994). Narratologisesta näkökulmasta tämä musiikki on ei-diegeettistä: tiedämme, että se kuuluu elokuvakerronnan konventioihin ja että sillä ei ole mitään konkreettista reaalimaailman lähdettä tarinan sisällä. Scarlettin vieressä pellolla ei ole orkesteria soittamassa. Scarlett ei myöskään itse kuule musiikkia, vaan musiikki on läsnä vain meitä katsojia varten. Se on 
myös niin sanottua taustamusiikkia: se ei häiritse puheen kuuluvuutta, vaan myötäilee ja tukee sitä. Musiikki ei vain vahvista kohtauksen tunnelmaa, vaan voi jopa sanoa, että se luo kohtauksen sisältämän tunnelatauksen. Elokuvien musiikki on tunnetta (Gorbman 1987). Ei-diegeettinen musiikki toimii siis kohtauksen lukuohjeena katsojalle: sen voi ajatella eräänlaisena kertojan äänenä, joka kertoo katsojille miltä Scarlettista tuntuu juuri sillä hetkellä (ks. Heldt 2013). Musiikki voimistuu ja nousee etualalle vasta kun puhe on saatu päätökseen. Samalla kamera loittonee Scarlettista muodostaen tietynlaisen eeppisen nosteen: Scarlettista tulee sen myötä elämää suurempi.

Toisenlaista lähestymistapaa musiikkiin elokuvassa edustaa "Stuck In The Middle With You" -laulun käyttö Quentin Tarantinon elokuvassa Reservoir Dogs (USA 1992). Alkuperäismusiikin sijaan kyseessä on valmiin, jo ennalta tunnetun pop-kappaleen sisällyttäminen elokuvan tarjoamaan uuteen kontekstiin. Laulu kuullaan elokuvassa diegeettisenä eli sillä on realistiseksi miellettävä lähde elokuvan tarinamaailmassa: tehdashallissa on radio, jonka toinen kohtauksen henkilöhahmoista laittaa suurieleisesti päälle ja sitten tanssii ja laulaa musiikin tahdissa. Radiosta kuuluu juontajan ääni, joka kertoo, että seuraavaksi kuulemme Stealers Wheel -yhtyeen musiikkia. Kappale ei siis soi huomaamatta taustalla, vaan sen alkamiseen ja läsnäoloon kiinnitetään huomiota sekä henkilöhahmojen toiminnan että dialogin kautta. Tämä musiikki ei alleviivaa tai korosta kohtauksen tunnetta tai tunnelmaa, vaan itse asiassa päinvastoin, sen voi jopa ajatella olevan ristiriidassa sen kanssa. Laulu alkaa soimaan ja huolimatta siitä, että seuraavassa hetkessä toinen miehistä hyökkää toisen kimppuun ja pahoinpitelee tätä brutaalisti, kappale jatkaa iloista kulkuaan piittaamatta toisen hahmon hädästä. Michel Chion (1994) puhuu anempaattisesta musiikista (anempathetic music). Kappaleen yhteensopimattomuus toimii oikeastaan sen soittamaan laittaneen miehen luonteenkuvauksena korostaen hänen tunteettomuuttaan uhria kohtaan, mahdollisesti jopa sairasta mieltä.

Näiden kahden esimerkin myötä havainnollistuu, miten elokuvien musiikinkäytössä aktivoituu usein sarja konventionaalisia oppositiopareja: alkuperäinen - lainattu, klassinen - populaari, instrumentaali - laulettu, ei-diegeettinen - diegeettinen, tausta - etuala, kertojan ääni - henkilöhahmon ääni, tunne - anempatia, eeppinen/fantastinen - realistinen. Näiden dikotomioiden ensimmäisten ominaisuuksien klusterista voimme käyttää nimitystä Elokuvamusiikki 1 ja jälkimmäisestä klusterista nimitystä Elokuvamusiikki 2. On kuitenkin tärkeä huomata, että konkreettisia kohtauksia ja niissä käytettyjä musiikkikatkelmia tarkasteltaessa ei ole kyse sen määrittämisestä, noudattavatko ne ensimmäistä vai jälkimmäistä varianttia. Ominaisuusklusterit Elokuvamusiikki 1 ja Elokuvamusiikki 2 ovat teoreettisia arkkityyppejä. Elokuvamusiikin rooli ja merkitys hahmottuvat analysoimalla, miten yksittäinen katkelma navigoi tiensä näiden vastakohtaparien läpi. Yksittäisten kohtausten musiikinkäytössä toiset ominaisuudet voivat korostua, kun taas toiset jäävät merkityksettömiksi. Suhtautuminen saattaa jopa muuttua kesken kaiken.

Esimerkkinä tällaisesta muutoksesta on melko tuoreen Drive -elokuvan (USA, 2011) kohtaus, jossa Desiree-yhtyeen kappale "Under Your Spell" alkaa diegeettisenä musiikkina, jota soitetaan erään pariskunnan kotona järjestetyssä juhlassa. Juhlakuvauksen lomaan on leikattu kuvia elokuvan miespäähenkilöstä omassa asunnossaan työskentelemässä pöytänsä ääressä. Hänen asuntoonsa sama musiikki kuuluu vaimeana luoden illuusion realistisesta äänilähteestä naapurissa, jossa juhlitaan. Juhlien emäntää kuvattaessa, kamera alkaa lähestyä häntä ja samalla musiikin äänenvoimakkssus kasvaa Tämän kasvun ja kameran liikkeen yhteisvaikutuksesta laulun sanat "I don't eat, I don't sleep / I do nothing but think of you" muuttuvatkin henkilöhahmon sisäiseksi monologiksi. Ristileikkaus naapurissa korjaustöitä tekevään mieheen luo selvän yhteyden heidän välilleen. Ei jää epäilystä siitä, kehen emännän 
tunne kohdistuu, tai siitä, että tunne on molemminpuolinen. Yksi ja sama musiikkikatkelma siirtyy siis kohtauksen edetessä realistisesta diegeettisestä juhlamusiikista ei-diegeettiseksi eeppisen tunteen kuvaukseksi. Musiikin siirtymät kerronnan tasojen välillä ovat myös siirtymiä siinä, kenen äänenä musiikki kuullaan, millä tavalla se osallistuu tunnetilojen kuvaukseen ja kuinka realistisena tai konventionaalisena tai fantastisena sen läsnäolo koetaan.

Se, että elokuvamusiikin arkkityyppien näennäisesti vastakkaisten ominaisuuksien rajat hämärtyvät ja sekoittuvat käytännön esimerkeissä, ei missään nimessä tarkoita sitä, että käsiteparit olisivat hyödyttömiä elokuvien musiikinkäytön tarkastelussa. Päinvastoin: juuri nämä siirtymät ovat avaimia siihen, miten musiikkikatkelmat osallistuvat elokuvien merkityksenluontiin. Nämä käsiteparit toimivat hyödyllisinä välineinä elokuvien musiikinkäytön yksityiskohtaisessa analyysissa, ja sen myötä tarjoavat myös lähtökohdan elokuvamusiikin konventioiden vertailevaan tarkasteluun eri aikakausina ja eri kulttuurikonteksteissa.

Väitöskirjassani olen analysoinut rock-musiikinkäyttöä useassa neuvostoaikaisessa elokuvassa, minkä perusteella voin alustavasti esittää, että neuvostoelokuvien konventionaalinen musiikistrategia on perusrakenteeltaan dualistinen. On ensisijainen musiikki, jota voi nimittää vaikkapa elokuvan keskeiseksi musiikilliseksi idiomiksi. Se on alkuperäistä instrumentaalimusiikkia, jota käytetään ei-diegeettisenä taustamusiikkina korostamaan tarinaan sisältyviä tunnetiloja sekä välillä antamaan viitteitä jonkinlaisesta eeppisen kerronnan tasosta. Pääidiomi on usein hyvin samankaltainen sen arkkityypin kanssa, josta käytin nimitystä Elokuvamusiikki 1. Tässä tulee kuitenkin tärkeä ero neuvostoelokuvien musiikinkäytössä verrattuna paljon tutkittuun Hollywoodin musiikinkäyttöön: neuvostoelokuvassa musiikkia ylipäänsä käytetään vähemmän. Teoreetikot Korganov ja Frolov (1964) selittävät tämän liittyvän käsitykseen siitä, että liiallinen tunteellisen konventionaalisen musiikin käyttö mielletään amerikkalaisuuden jäljittelyksi, mistä syystä sitä ehkä hieman turhaankin kavahdetaan. Sosialistisen realismin ihanne tuntuisi vaativan hieman pidättyväisempää suhtautumista tällaisen musiikin ja erityisesti ei-diegeettisen musiikin käyttöön.

Dikotomiaan perustuvan musiikkistrategian toinen puoli on monessa suhteessa pääidiomille vastakkainen musiikillinen poikkeama. Käytännössä tämä tarkoittaa useimmiten populaarikappaleita. Neuvostokontekstissa populaarikappale tai -laulu käsittää hieman erilaisen repertuaarin kuin läntisessä, angloamerikkalaisessa perinteessä. Neuvostoelokuvien laulut viittaavat yleensä elokuvaa varten sävellettyihin alkuperäislauluihin: 1930-luvulla marsseihin ja 1960-luvulta alkaen lyyrisiin balladeihin, bardien repertuaariin tai kansanlauluihin (Egorova 1997). Lähestulkoon aina tällaiset laulut esitetään diegeettisinä tarinaan upotettuina lauluesityksinä. Joku henkilöhahmoista tarttuu kitaraan ja laulaa laulun ilman, että elokuva on lajityypiltään musikaali. Nämä lauluperformanssit kontrastoituvat elokuvan musiikkistrategian pääidiomiin diegeettisyydellään sekä kohosteisuudellaan. Ne vastaavat arkkityyppiä Elokuvamusiikki 2 kaikilla muilla tasoilla paitsi siinä, miten pääidiomin tavoin ne myös ilmaisevat aitoa tunnetta. Ne kuvastavat lauluja esittävien ja kuuntelevien henkilöhahmojen syvimpiä, sisimpiä ajatuksia - ilman että nämä tunteet ja ajatukset millään lailla kontrastoituvat elokuvan kertojaposition kanssa. Tyyppiesimerkiksi käy elokuvan Sotakaverit (Belorusskij vokzal, Neuvostoliitto 1971) kohtaus, jossa naispäähenkilö Raia (Nina Urgant) tarttuu kitaraan ja laulaa Bulat Okudžavan kirjoittaman sotalaulu-mukaelman "My za tsenoj ne postoim" ["Me emme kysy hintaa"]. Miehet, jotka koko elokuvan ajan ovat levottomina kierrelleet ympäri Moskovaa etsien jotain ulospääsyä sodan kokeneen sukupolven traumaan, saavat vihdoin tulkin tunteilleen tämän tekstin ja kitaraesityksen kautta. Ensin he kyynelehtivät valtoimenaan ja lopulta yhtyvät itsekin lauluun. 
Kahtiajako diegeettisinä poikkeamina esitettyjen lauluperformanssien ja pääidiomiksi tarkoitetun huomaamattomamman alkuperäismusiikin välillä ei ole ollut mitenkään vieras yhdysvaltalaiselle elokuvakulttuurillekaan. Mutta kaupallisen populaarimusiikin lopullisen läpilyönnin ja erityisesti rock-musiikin esille marssin jälkeen angloamerikkalaisten elokuvien laulut siirtyivät parissa vuosikymmenessä tarinoiden sisältä tarinoiden ulkopuolelle: pop- ja rock-laulut muuttuivat diegeettisestä kerronnan sisällöstä ei-diegeettiseksi kerronnan välineeksi. Viimeistään 1980-luvun hittisoundtrackit vakiinnuttivat pop- ja rock-kappaleet täysin kelvollisiksi koko elokuvan kattaviksi pääidiomeiksi. Näin syntyivät niin sanotut kompilaatio- ja komposiitti-scoret (Smith 1998; Reay 2004).

Neuvostokontekstissa vastaavaa kehityskulkua ei tapahtunut samalla aikavälillä. Toisin kuin usein luullaan, rock-kappaleita saattoi kyllä esiintyä yksittäisissä elokuvissa aina 1960-luvulta alkaen. Konventionaalisen musiikkistrategian kannalta tämä tarkoitti sitä, että näissä tapauksissa alkuperäisen binaariopposition sisälle syntyi uusi, upotettu binaarioppositio. Rockkappaleet asettuvat vastakkain muiden, hyväksytympien populaarilaulujen muotojen kanssa. Kummatkin laulutyypit esitetään diegeettisinä ja kohosteisina esityksinä, mutta vastakkaisuus niiden välille syntyy siinä, kuinka hyvin laulu kykenee ilmaisemaan henkilöhahmojen tunteita ja sisäistä maailmaa. Neuvostoelokuvassa rock-kappaleet eivät liity mielen liikkeisiin, vaan kehollisuuteen, sillä ne esitetään yleensä kohtauksissa, joissa tanssitaan. Rock esitetään siis tyhjänpäiväisenä ja pinnallisena - ja usein vielä sangen koomisessa valossa.

Esimerkki tällaisesta hassusta rock-laulusta löytyy myös Sotakaverit-elokuvasta. Kamerton-niminen yhtye on pukeutunut Beatles-henkisiin asuihin ja esittää kappaleensa "My orjom na vsju katušku" ["Huudamme täyttä kurkkua"]. He esiintyvät trendikkäässä ravintolassa, jonne elokuvan päähenkilöt, keski-ikäiset sotaveteraanimiehet ovat kokoontuneet toverinsa hautajaisten jälkeen. Laulun sanoista ja esityksestä muodostuu humoristinen ja itseään reflektoiva vastapaino miesten pyrkimykselle puhua syvällisesti: "Laulamme täyttä kurkkua ja häiritsemme teidän keskustelua" on laulun tekstisisältö. Laulun ja sitä tanssivan nuorison sekä surullisten vanhojen miesten välille syntyy tragikoominen vastakkainasettelu, jossa ei ole epäselvää kumman puolelle elokuvan kertojapositio asettuu. Käytännössä kaikki esimerkit rock-musiikista 1960- ja 1970-luvun neuvostoelokuvissa sijoittuvat kohtauksiin, joissa orkesteri soittaa tai nuoriso tanssii tai kuuntelee musiikkia. Rock-musiikki liittyy siis vahvasti yhtäältä nuorison kuvaukseen ja toisaalta musiikin esittämisen tai kuuntelun kuvaukseen aktiivisena toimintana.

Perestroikan myötä tämä perusasetelma muuttui yllättävän vähän. Tuolloin tehtiin useampikin rock-elokuva, joissa kuvauksen kohteena on rock-kulttuuri itse ja rock-muusikoiden esittäminen valkokankaalla. Rock-kappaleita näissä elokuvissa esiintyi sen verran paljon, että rockia voi perustellusti jo pitää näiden elokuvien pääidiomina. Mutta näissäkään tapauksissa rock-laulut eivät ole pääidiomina yksin. Ikään kuin elokuvien musiikkistrategiaa ei olisi uskallettu rakentaa pelkästään rock-kappaleiden varaan; edelleenkään ei luoteta täysin niiden kykyyn välittää kaikkea sitä informaatiota mitä pääidiomin tehtäviin usein kuuluu. Tällä kertaa binaariopposition ensimmäinen osapuoli kahdentuu: pääidiomina toimii yhdistelmä alkuperäistä instrumentaalimusiikkia ja rock-lauluja. Ja mielenkiintoista kyllä, vanhemmalta neuvostoajalta peräisin oleva eri laulutyyppien kahtiajako säilyy edelleen - nyt roolit ovat vain kääntyneet ympäri. Rock-laulut välittävät syvää ja älyllistä tunnesisältöä, kun taas muut laulutyypit edustavat pinnallisuutta ja tyhjänpäiväisyyttä. 
Voi perustellusti väittää, että Aleksei Balabanovin Veli (Brat, Venäjä 1997) esittelee ensimmäisen todellisen venäläisen rock-lauluista koostuvan kompilaatio-soundtrackin. Pääidiomi koostuu yksinomaan rock-lauluista. Silti edelleen on läsnä neuvostoajalta peritty dikotomia syvällisten laulujen ja pinnallisten laulujen välillä. Samalla täydeksi pääidiomiksi ylennetyt rock-laulut ikään kuin epäröivät uudessa roolissaan. Ne heiluvat diegeettisyyden molemmin puolin ikään kuin pohtien, minkä mallin mukaan toimia: neuvostoajan konvention, perestroikan konvention vai modernimman, läntisessä elokuvassa käytetyn musiikkistrategian mukaan. Onko elokuva realistinen kuvaus nuoresta miehestä, joka pitää rock-musiikin kuuntelusta vai onko se fantastissävytteisempi kuvaus eeppisen uuden ajan sankarin synnystä? Musiikinkäytön epäröinti heijastuu suoraan elokuvan genren ja merkityksen määrittämiseen. Samalla pääidiomin epäröivä käytös voidaan nähdä tärkeänä askeleena venäläisen elokuvamusiikin konventioiden evoluutiossa: Veli-elokuvan myötä rock-lauluista on vihdoin tulossa sitä "oikeaa" elokuvamusiikkia.

Veli-elokuvan tarinamaailma eli diegesis on täynnä realistisia musiikkiteknologian eri ilmentymiä, eri tapoja kuunnella ja kuluttaa musiikkia: CD-levyjä, LP-levyjä, radiovastaanottimia ja elävää musiikkia. Siihen on myös sisällytetty useita eri tapoja yhdistää ja tallentaa musiikkia kuvan kanssa: on konserttiesitys, VHS-konserttitaltiointi ja kalliisti tehty musiikkivideo. Elokuva sisältää lisäksi dokumentaarisen kohtauksen keski-ikäistyvistä perestroika-ajan rock-muusikoista ja jopa humoristisen tanssikohtauksenkin. Siitä huolimatta, että elokuvassa on kiinnitetty näin paljon visuaalista huomiota musiikin eri esittämisen muotoihin, elokuvan tarina ei päällisin puolin keskity kertomaan musiikista, musiikin tekemisen kulttuurista tai sen kuuntelusta, vaan se on gangsteritarina nuoren miehen seikkailuista Pietarin alamaailmassa. Näiden kaikkien eri musiikkia ja kuvaa yhdistävien variaatioiden sisällyttäminen näennäisesti aivan muista asioista kertovaan elokuvaan on vahva itsereflektion merkki: elokuva ei vain käytä musiikkia tietyllä tavalla, vaan samanaikaisesti kommentoi itse sitä omaa käyttötapaansa. Veli on yksi lenkki venäläisen elokuvamusiikin evoluutioketjussa. Se on samalla hyvin tietoinen asemastaan ja roolistaan tässä ketjussa.

Ohjaaja Balabanov jatkoi Veli-elokuvan jälkeen pop- ja rock-laulujen käytön mahdollisuuksien tarkastelua lähes kaikissa myöhemmissä elokuvissaan. Gruz 200 (Venäjä 2006) ja Kotšegar (Venäjä 2010) käyttävät molemmat omalla tavallaan populaarikappaleita kuvaamaan kollektiivista anempatiaa sekä neuvostoajan että sen jälkeisen yhteiskunnan kriittisimpinä hetkinä. Kummankin elokuvan musiikkistrategia sai aikaan pienen kohun Venäjällä herättäen jopa vihaa, mikä on ilman muuta merkittävä saavutus mille tahansa 2000-luvun puolella tehdyn elokuvan musiikkiraidalle.

Balabanovin viimeiseksi elokuvaksi jäi Tarkovski-pastissi Ja tože hotšu (Venäjä 2012). Se on tarina gangsterista, rock-muusikosta ja elokuvaohjaajasta onneaan etsimässä. Elokuvan musiikkistrategia rakentuu ei-diegeettisesti kuulluille Auktsyon-yhtyeen rock-kappaleille, joita käytetään yhdessä futuristis-elektronisen alkuperäismusiikin kanssa; joskus molempia kuullaan jopa yhtä aikaa. Mutta elokuva sisältää myös yhden sangen perinteisesti rakennetun diegeettisen musiikkiesityksen: elokuvan muusikko-hahmo (Auktsyon-yhtyeen Oleg Garkuša) on kantanut läpi koko elokuvan kitaralaukkua mukanaan. Kitaraan ei kiinnitetä juurikaan huomiota ennen kuin leirinuotion ääressä toverit pyytävät muusikkoa laulamaan jotain. Garkuša ottaa juhlallisesti kitaran laukustaan, asettaa huolellisesti lasit nenälleen ja epävireisesti kitaraansa rämpyttäen alkaa huutaen deklamoida tekstiä, joka kuvaa lyhyttä kohtaamista kodittomien juoppojen kanssa. Kun esitys on ohi, pyyhkäisee hän silmäkulmastaan kyyneleen. Performanssin voi nähdä suorana viitteenä neuvostoajan elokuvien 
musiikkiesitysten perinteeseen. Muodoltaan räävitön ja brutaali rock-esitys toimii tälläkin kertaa mitä syvimpien tuntojen tulkkina - ei ehkä kertojan tai kuulijoiden näkökulmasta, mutta ainakin esiintyjälle itselleen.

Kun poikani vielä vähän kasvaa, hän huomaamattaan oppii hahmottamaan elokuvien musiikin liikkeitä diegeettisyyden ja ei-diegeettisyyden välillä - samalla tapaa kuin me kaikki olemme oppineet. Hän tulee myös alitajuisesti tulkitsemaan näiden liikkeiden mukanaan tuomat merkitykset ja niiden sisältämät semioottiset ja narratologiset dikotomiat. Mutta nämä viattoman rehelliset ja suoraviivaiset kysymykset ja pohdinnat "Mistä tuo musiikki tulee?" ja "Mikä tämä laulu on?" ovat olennaisia kehityksen välivaiheita, oli kyse sitten ihmisyksilöstä oppimassa taiteen kielen konventioita tai kokonaisista kulttuureista laajentamassa omaa ilmaisurepertuaariaan.

Tässä lektiossa esittämäni yksinkertaistukset ja dikotomiat perustuvat väitöskirjassani tehdylle useiden elokuvien musiikinkäytön tarkalle lähiluvulle tiettyjen taiteen, elokuvan ja elokuvamusiikin rakennetta kuvaavien teorioiden valossa. Mutta tämä työ on vasta ensimmäinen vaihe, sillä tarvitaan vielä lisää tietoa ja perehtymistä. Elokuvien purkamista esittämäni metodin avulla tulee jatkaa, jotta elokuvamusiikin käyttöön liittyvien konventioiden määrittäminen eri aikakausina tarkentuu. Lisäksi on tarvetta kulttuurisidonnaisemmalle keskustelulle siitä, miksi tietyt konventiot ovat syntyneet tietyissä konteksteissa tiettyinä ajanjaksoina, miksi ne ovat sitten kehittyneet tiettyihin suuntiin ja miksi eri konteksteissa kehitys on ollut erilaista - vai onko sittenkään? Tutkimukseni ei anna tyhjentäviä vastauksia näihin kysymyksiin, vaan määrittää vasta yhden musiikkityypin kehityksen elokuvan rakenne-elementtinä tietyssä kontekstissa. Minun näkökulmastani mielenkiintoinen ja jännittävä matka on vasta alussa.

\section{Lähteet}

Brown, Royal S. (1994), Overtones and Undertones. Reading Film Music. London, Berkeley \& LosAngeles: University of California Press.

Chion, Michel (1994), Audio-vision. Sound on Screen, (käännös Claudia Gorbman), New York: Columbia University Press.

Egorova, Tatiana K. (1997), Soviet Film Music. An Historical Survey (käännös Tatiana A. Ganf \& Natalia A. Egunova), Amsterdam: Harwood Academic Publishers.

Gorbman, Claudia (1987), Unheard Melodies. Narrative Film Music. Bloomington \& London: Indiana University Press \& BFI Publishing.

Heldt, Guido (2013), Music and Levels of Narration in Film. Steps Across the Border. Bristol \& Chicago: Intellect.

Korganov, T. \& Frolov, I. (1964), Kino i muzyka. Muzyka v dramaturgii filma. Moskva: Iskusstvo. Reay, Pauline (2004), Music in Film. Soundtracks and Synergy. London: Wallflower.

Smith, Jeff (1998), Sounds of Commerce. Marketing Popular Film Music. New York: Columbia University Press.

MA Ira Österbergin musiikkitieteen alaan kuuluva väitöskirja What Is That Song? Aleksej Balabanov's Brother and Rock as Film Music in Russian Cinema tarkastettiin keskiviikkona 9.5.2018 klo 12 Helsingin yliopiston humanistisessa tiedekunnassa. Vastaväittäjänä toimi Senior Lecturer Guido Heldt (University of Bristol) ja kustoksena professori Pirkko Moisala. 


\section{SINÄ + NÄMÄ KIRJAT = SAATAVIILIA MAUPOISTA JA INTOKUSTANWUS.FI}

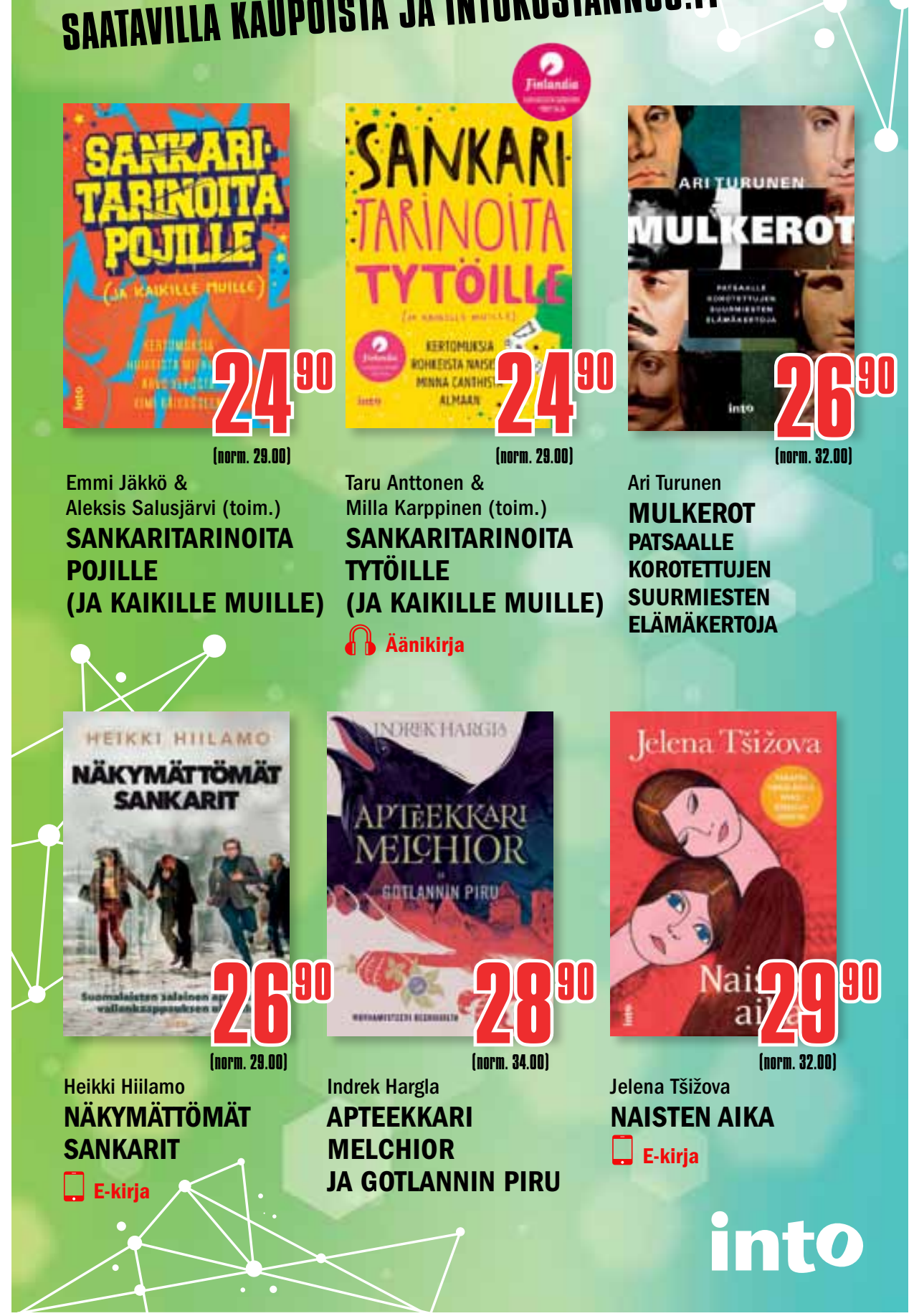

